\title{
AWARENESS AMONG NURSING STUDENTS ABOUT CARE FOR CHILDREN WITH TYPE 1 DIABETES
}

\section{DZIECKO Z CUKRZYCĄ TYPU 1 W ŚWIADOMOŚCI STUDENTÓW PIELĘGNIARSTWA}

\author{
Anna Lawnik ${ }^{1(A, B, C, D, E, F, G)}$, Anna Pańczuk ${ }^{1(A, B, C, D, E, F, G)}, Z^{2}$ ofia Kubińska ${ }^{1(A, B, C, D, E, F, G)}$ \\ ${ }^{1}$ Pope John Paul II State School of Higher Education in Biała Podlaska, Poland
}

Authors' contribution Wkład autorów: A. Study design/planning zaplanowanie badań B. Data collection/entry zebranie danych C. Data analysis/statistics dane - analiza i statystyki D. Data interpretation interpretacja danych E. Preparation of manuscript przygotowanie artykułu F. Literature analysis/search wyszukiwanie i analiza literatury G. Funds collection zebranie funduszy

Tables: 2

Figures: 0

References: 19

Submitted: 2019 Feb 22

Accepted: 2019 March 30

\section{Summary}

Background. Diabetes, due to its prevalence and the rapid increase in the number of new incidences, has been recognized as an epidemic of the 21st century. It is estimated that over 3 million people in Poland currently suffer from this disease. According to the Ministry of Health, the knowledge of the society about diabetes is too little and insufficient. The aim of the study was to investigate and present general and expert knowledge of nursing students about type 1 diabetes, taking into account the needs of a child and the specialist skills required to care for diabetic children.

Material and methods. The study was conducted among the students of nursing at Pope John Paul II State School of Higher Education in Biała Podlaska. A questionnaire designed by the author was used in this study.

Results. The respondents reported that they possess basic knowledge about type 1 diabetes and at the same time are willing to learn more. They recognize that a child with type 1 diabetes requires special support, therefore medical personnel, educators and physical education teachers should have relevant knowledge and skills about care for type 1 diabetic children.

Conclusions. The majority of the students surveyed had a basic knowledge and skills enabling them to provide assistance to children with type 1 diabetes and are familiar with their needs. The significance of physical activity in the life of a child with type 1 diabetes was known to a lesser extent. The students surveyed are willing to broaden their knowledge about type 1 diabetes.

Keywords: diabetes, child, care

\section{Streszczenie}

Wprowadzenie. Cukrzyca z racji częstości występowania i szybkiego wzrostu liczby nowych zachorowań została uznana za epidemie XXI wieku. Szacuje się, że aktualnie w Polsce choruje ponad $3 \mathrm{mln}$ ludzi. Zdaniem Ministerstwa Zdrowia wiedza społeczeństwa na temat cukrzycy jest zbyt mała i niewystarczająca. Celem pracy było zbadanie i przedstawienie wiedzy ogólnej i specjalnej studentów pielęgniarstwa na temat cukrzycy typu $1 \mathrm{z}$ uwzględnieniem potrzeb dziecka oraz umiejętności umożliwiających pomoc choremu dziecku.

Materiał i metody. Badania przeprowadzono wśród studentów kierunku pielęgniarstwo Państwowej Szkoły Wyższej im. Papieża Jana Pawła II w Białej Podlaskiej. W badaniach zastosowano autorski kwestionariusz ankiety.

Wyniki. Badani ocenili, iż posiadają podstawową wiedzę na temat cukrzycy typu 1 , a jednocześnie sa chettni ja pogłębić. Przyznaja, że dziecko z cukrzyca typu 1 wymaga szczególnego wsparcia, dlatego personel medyczny, pedagodzy oraz nauczyciele wychowania fizycznego powinni posiadać wiedzę i umiejętności z zakresu cukrzycy typu 1.

Wnioski. Badani studenci $w$ zdecydowanej większości posiadają podstawową wiedzę i umiejętności umożliwiające pomoc dziecku z cukrzycą typu 1 oraz znają potrzeby chorego dziecka. Zdrowotne znaczenie aktywności fizycznej w życiu dziecka z cukrzycą typu 1 jest znane badanym w mniejszym zakresie. Badani studenci zgłaszają chęć poszerzenia swojej wiedzy na temat cukrzycy typu 1.

Słowa kluczowe: cukrzyca, dziecko, opieka 


\section{Introduction}

Diabetes is so called a 'life-style' disease, and due to the steadily increasing incidence has been considered an epidemic of the 21st century and one of the main threats to the health and life of the population [1].

New data published by the World Health Organization (WHO) indicate that, according to the estimates, in 2014 there were 422 million adults with diabetes in the world (compared to 108 million in 1980). The information contained in Poland's national profile, which is part of the WHO's first global report on the disease, shows that diabetes causes $2 \%$ of all deaths in the country [2].

There are no comprehensive nationwide registers of people with diabetes. However, in Poland, it is estimated that about 2-3 million people suffer from diabetes, about 25\% of whom are unaware of it. In total, the incidence of diabetes is about $6.54 \%$ (including $5.81 \%$ men and $7.25 \%$ women) [3].

For people over 18 years of age, this ratio is $8 \%$ (including $7.15 \%$ men and $8.9 \%$ women), while for children under 15 years of age, the estimated number of diabetics is 17.7 cases per 100,000 inhabitants. According to estimates in the next 15 - 20 years the number of people with diabetes will double in Poland. Type 1 diabetes account for about $10 \%$ of the total number of people suffering from the disease. The onset of the disease usually falls between 10 and 14 years of age $[3,4]$.

The occurrence of type 1 diabetes is associated with the destruction of pancreatic B cells by the immune system of the owner. The result is a lack of insulin in the patient's body, which leads to hyperglycemia [5, 6, 7]. As indicated by the Polish Diabetes Association of 2018, chronic hyperglycemia may lead to damage, insufficiency and impairment of many different organs, in particular: eyes, kidneys, heart, blood vessels and nervous system [5]. According to the Ministry of Health, a significant increase in the incidence of this chronic disease has been observed for many years, and this phenomenon mainly affects children in the first years of their lives [8].

A person suffering from diabetes should be able to lead a normal, healthy and long life. However, in order to achieve this goal, it is necessary to constantly deepen the knowledge about the disease, systematically monitor glycemic levels, calculate the calorific intake of meals and conduct appropriate insulin therapy [2, 8, $9,10]$. As Joslin, the creator of modern diabetology, stated, "the sick who know the most live the longest" [11]. Moreover, rationally planned and implemented physical activity plays an important role in the treatment of type 1 diabetes. Regular physical activity has a positive effect on the body's need for insulin, normalizes cholesterol levels and decreases the incidence of cardiovascular diseases. Movement also stimulates muscle development, has a positive effect on the peripheral and central nervous system, improves the patient's condition and general well-being $[11,12]$.

In order to ensure full motor development of a diabetic child, it is necessary to enable the child to participate in physical education classes, also at school. However, it should be remembered that too intensive physical exercise can lead to a decrease in blood glucose levels and, consequently, even cause dangerous hypoglycemia. The safety of a child with type 1 diabetes, at an educational facility, should be ensured by the principal, educators, form teachers, including a physical education teacher. According to the information of the Ministry of Health, the knowledge of the whole society about diabetes, including educators, is too little and insufficient [8]. Lack of knowledge among educators results in difficulties in caring for sick children and raises concerns, both among parents and educators themselves. Therefore, the situation may have a negative impact on the implementation of compulsory education by children with type 1 diabetes [8].

The aim of the study was to investigate and present the general and special knowledge of nursing students about type 1 diabetes, taking into account the needs and the specialist pediatric care required.

\section{Material and methods}

This study was carried out among the nursing students at Pope John Paul II State School of Higher Education in Biała Podlaska. 89 students (4th year of undergraduate studies and 2nd year of supplementary master's studies) aged 22-54 years (mean 26.8; SD=7.5) were surveyed.

The majority of the respondents were women (87.6\% of the total number of the respondents). The percentage of inhabitants of cities and rural areas was, respectively: $52.8 \%$ and $47.2 \%$. Among the surveyed students, $21.3 \%$ have a person with type 1 diabetes among their friends and relatives, $74.2 \%$ do not have a diabetic person in their environment, and $4.5 \%$ declared lack of knowledge about it.

In this study, the author's questionnaire was used. It contained 21 closed questions related to general and special knowledge and skills in the field of type 1 diabetes, one open question concerned subjects (classes), during which the respondents gained knowledge and skills required to handle the problem. The questionnaire also included personal information (age, gender, place of residence, year of studies) and a question aimed to establish whether the respondents have a person with type 1 diabetes among their friends and relatives. 


\section{Results}

The students have assessed that they had basic knowledge about type 1 diabetes (98.9\%). At the same time, most of them show interest in deepening their knowledge about diabetes (84.3\%), 12.4\% are not interested in doing so. $85.4 \%$ of the respondents declared their willingness to acquire professional skills enabling them to support and help people suffering from type 1 diabetes, with particular emphasis on children. The majority of respondents believe that children with type 1 diabetes are at risk of additional school stress (86.5\%) and require targeted support from the school environment (94.4\%) (principal's office, teachers and service staff). Detailed results concerning particular aspects of the students' knowledge about the disease and functioning of a child with type 1 diabetes at school can be found in Table 1.

Table 1. General awareness of type 1 diabetes pediatric care in the students surveyed (\%)

\begin{tabular}{|c|c|c|c|}
\hline $\begin{array}{l}\text { General knowledge about type } 1 \text { diabetes } \\
\text { and the needs of a child }\end{array}$ & Yes & No & I don't know \\
\hline I have basic knowledge of type 1 diabetes. & 98.9 & - & 1.1 \\
\hline I am interested in learning more about type 1 diabetes. & 84.3 & 12.4 & 3.4 \\
\hline $\begin{array}{l}\text { I am interested in gaining professional skills to support and help } \\
\text { people with type } 1 \text { diabetes, especially children. }\end{array}$ & 85.4 & 6.7 & 7.9 \\
\hline $\begin{array}{l}\text { Children with type } 1 \text { diabetes require additional support from the } \\
\text { school environment. }\end{array}$ & 94.4 & 3.4 & 2.2 \\
\hline $\begin{array}{l}\text { Pupils with type } 1 \text { diabetes are exposed to additional school stress } \\
\text { (health, anxiety, peer relationships). }\end{array}$ & 86.5 & 11.2 & 2.3 \\
\hline $\begin{array}{l}\text { Medical students should have professional knowledge and skills in } \\
\text { the field of type } 1 \text { diabetes. }\end{array}$ & 96.6 & 1.1 & 2.3 \\
\hline $\begin{array}{l}\text { Students of pedagogical faculties should have professional } \\
\text { knowledge and skills in the field of type } 1 \text { diabetes. }\end{array}$ & 89.9 & 7.9 & 2.2 \\
\hline $\begin{array}{l}\text { Care and assistance provided to a child with type } 1 \text { diabetes } \\
\text { should be a required professional competence of teachers (form } \\
\text { teachers, educators). }\end{array}$ & 80.9 & 11.2 & 7.9 \\
\hline $\begin{array}{l}\text { A physical education teacher should be able to diagnose conditions } \\
\text { threatening the health of a child with diabetes and help. }\end{array}$ & 95.5 & 3.4 & 1.1 \\
\hline $\begin{array}{l}\text { A physical education teacher should encourage a child to } \\
\text { systematically participate in physical education classes. }\end{array}$ & 92.0 & 2.3 & 5.7 \\
\hline The Polish society has basic knowledge about type 1 diabetes. & 20.2 & 70.8 & 9.0 \\
\hline
\end{tabular}

The vast majority of the surveyed students declared that they knew the symptoms of hypo-and hyperglycemia (89.8\%, 83.9\%), proper glucose parameters (86.5\%), as well as the differences between type 1 and 2 diabetes (73.0\%). They are also able to perform the necessary diagnostic activities (blood glucose measurement $97.7 \%$ ). More than half of the respondents are convinced of the need of an affected child to participate in physical education classes (63.2\%) and sports trainings (51.1\%), some of them stated that partial physical activity of the child in both forms of activities would be a better solution (34.5\%, 43.2\%). The vast majority of respondents (73\%) stated that a child with diabetes should have special rights on the tests (eating, drinking, using the toilet, prolonging the credit period, controlling the glycemic levels). The results are presented in Table 2.

Table 2. Specialist knowledge and skills of respondents about type 1 diabetes pediatric care, including assisting sick children (\%)

\begin{tabular}{|c|c|c|c|c|}
\hline \multirow[b]{2}{*}{$\begin{array}{l}\text { Special knowledge on type } 1 \text { diabetes } \\
\text { and care for sick children }\end{array}$} & \multicolumn{2}{|c|}{ Yes } & \multicolumn{2}{|c|}{ No } \\
\hline & definitely & partially & $\begin{array}{l}\text { but I would } \\
\text { like to know } \\
\text { / perform }\end{array}$ & $\begin{array}{l}\text { I am not } \\
\text { interested in it }\end{array}$ \\
\hline $\begin{array}{l}\text { I know the differences between type } 1 \\
\text { and } 2 \text { diabetes. }\end{array}$ & 73.0 & 25.8 & 1.1 & - \\
\hline I know the symptoms of hypoglycemia. & 89.8 & 10.2 & - & - \\
\hline I know the symptoms of hyperglycemia. & 83.9 & 14.9 & 1.2 & - \\
\hline $\begin{array}{l}\text { I can measure blood glucose using the necessary } \\
\text { equipment. }\end{array}$ & 97.7 & - & 2.3 & - \\
\hline
\end{tabular}




\begin{tabular}{|c|c|c|c|c|}
\hline $\begin{array}{l}\text { I know the correct parameters of the glucose } \\
\text { level in a patient with type } 1 \text { diabetes. }\end{array}$ & 86.5 & 11.2 & 2.3 & - \\
\hline $\begin{array}{l}\text { A child with type } 1 \text { diabetes can participate in } \\
\text { physical education classes. }\end{array}$ & 63.2 & 34.5 & 2.3 & - \\
\hline $\begin{array}{l}\text { A child with type } 1 \text { diabetes can take part in } \\
\text { sports trainings. }\end{array}$ & 51.1 & 43.2 & 3.4 & 2.3 \\
\hline $\begin{array}{l}\text { A child with type } 1 \text { diabetes should have special } \\
\text { rights on the test (eating, drinking, using the } \\
\text { toilet, prolonging the credit period, controlling } \\
\text { the glycemic levels). }\end{array}$ & 73.0 & 25.8 & - & 1.1 \\
\hline
\end{tabular}

The majority of the surveyed students $(75.3 \%)$ declared that they had an opportunity to acquire sufficient knowledge about type 1 diabetes, and $22.5 \%$ assessed the acquired knowledge as partial. Only $2.2 \%$ of the respondents stated that they did not acquire sufficient knowledge, but they would like to do so. Among the subjects, in which it was possible to acquire knowledge and skills about type 1 diabetes, the students most often mentioned internal medicine and internal medicine nursing, nursing a patient with diabetes. Occasionally, responses included pediatrics and pediatric nursing, basics of nursing or dietetics. As part of the work experience program, $52.8 \%$ of the respondents declared direct contact with a pupil suffering from type 1 diabetes, and $10.1 \%$ had such a possibility to a limited extent. As many as $34.8 \%$ of respondents did not have such an opportunity but they would like to have such experience. On the other hand, $2.3 \%$ of the total number of students are not interested in having a direct contact with a pupil suffering from type 1 diabetes.

\section{Discussion}

In the published literature, to date, the assessment of the level of knowledge about type 1 diabetes has been rarely reported. In the available resources, the majority of the reports concern the disease itself, the assessment of the knowledge of respondents concerning diabetes, without making a division into type 1 and type 2 diabetes $[13,14,15,16]$, patients with diabetes [17], or people who have a sick family member [18]. There are no publications describing the knowledge about type 1 diabetes among future nurses, physiotherapists or teachers, i.e. people who, in the future, will come into contact with those suffering from this disease in the professional environment.

As shown by the results of author's own research, $84.3 \%$ of the respondents clearly indicated that they would be willing to broaden their knowledge of type 1 diabetes, although $98.9 \%$ of the respondents believe that they already have basic understanding of this subject. Similar conclusions were put forward by Janeczek with the team and Kłys and Gerstenkorn, who assessed the knowledge of nursing students about type 2 diabetes. The results of these studies indicate a clear need to increase the scope of education about diabetes in the studied group of students. The respondents even suggested creating a separate specialization in diabetes, which would help to broaden the knowledge of medical personnel $[14,16]$. The results of Dębska, who studied the general knowledge about diabetes of university students in Lublin, are in line with the above-mentioned research results. These findings led the author to state that the implementation of general education on diabetes is necessary [13].

The results of author's research also highlighted, optimistically, that $85.4 \%$ of the respondents are interested in gaining professional skills enabling them to support and help those suffering from type 1 diabetes, especially children. The respondents admitted that not only medical students should have professional knowledge and skills in the field of type 1 diabetes (96.6\%), but also students of pedagogical (89.9\%) and physical education (95.5\%) faculties.

The research conducted by Trojanowska and her team showed that only one in five children with diabetes had little knowledge about their disease, the possible treatment and self-monitoring [9], which may indicate that their education was insufficient or improperly conducted. It only highlights the fact that the vast majority of children with diabetes require additional information and help from others. The respondents (94.4\%) agreed that children with type 1 diabetes require additional support from the school environment.

It may be of concern that only $63.2 \%$ of the respondents stated that a child with type 1 diabetes can participate in physical education classes, and even less, because only $51.1 \%$ believe that a child with diabetes can take part in sports trainings. As already mentioned, physical exercise is necessary, since it has a positive effect not only on the treatment process of diabetics, but also on the improvement of the quality of life, well-being, positive self-esteem and self-confidence. Therefore, it cannot be limited or avoided, but prepared for in a rational and responsible manner [12]. Moreover, it might be thought-provoking that the same group of respondents (92\%) considered that a physical education teacher should encourage a child to systematically participate in physical education classes. 
The surveyed students (70.8\%) confirmed the opinion of the Ministry of Health that the Polish society does not have basic knowledge about type 1 diabetes [8]. Therefore, it is worth paying attention to the need to organize trainings in the field of knowledge, care and support for type 1 diabetic patients, especially in the communities of people, who in the future will have a direct, professional contact with diabetic patients. According to Zamarli M. - President of the National Federation of Diabetic Children and Youth Aid Organisations - teachers are afraid of taking over the care of a pupil with diabetes. They are reluctant to administer insulin to sick children, since not every teacher feels at the strength to make an injection and a vast number of people do not realize how different the genesis and treatment of type 1 and type 2 diabetes is. Some even think that you can get infected with diabetes. In one of the interviews, the president showed how difficult the situation of a child suffering from diabetes and its mother in the Polish school is; the mother who must resign from work when her child goes to school in order to provide an appropriate care [19].

According to Stefanowicz and his team, a contemporary nurse plays an essential role in the therapeutic education of a patient with type 1 diabetes - a professional who, apart from offering a sense of security and care, is also considered as a direct source of theoretical and practical knowledge and support in moments of doubt [11].

\section{Conclusions}

1. The majority of the students surveyed have basic knowledge and skills enabling them to help a child with type 1 diabetes and know the needs of a sick child.

2. The significance of physical activity in the life of a child with type 1 diabetes is known to a lesser extent.

3. The students surveyed are willing to broaden their knowledge about type 1 diabetes.

\section{References:}

1. Czupryniak L. [Diabetes as a life-style disease - epidemiological data]. In: Stepanow B, Brzozowska E, Matusiak E, Sobierajski T., editors. [Polish family with diabetes - report]. Warszawa: Stowarzyszenie Edukacji Diabetologicznej SED; 2018. p. 5 (in Polish).

2. Ministerstwo Zdrowia [Internet]. Warszawa: Ministerstwo Zdrowia; 2016. [WHO announces a new global report on diabetes] [cited 2018 Aug 20]. Available from: http://www.mz.gov.pl/aktualnosci/who-oglaszanowe-dane-o-cukrzycy-na-swiecie/ (in Polish).

3. Czupryniak L, Strojek K. [Diabetology]. Gdańsk: Wydawnictwo Via Medica; 2016 (in Polish).

4. Narodowy Fundusz Zdrowia [Internet]. Warszawa: Narodowy Fundusz Zdrowia. [Diabetes] [cited 2018 Aug 20]. Avaliable from: http://www.nfz.gov.pl/nfz-blizej-pacjenta/cukrzyca/ (in Polish).

5. Polskie Towarzystwo Diabetologiczne. [Clinical recommendations for diabetic patients 2018. Polish Diabetes Association's stance]. Diabetologia Praktyczna. 2018; 4(1) (in Polish).

6. Chrzanowska J, Salmonowicz B, Zubkiewicz-Kucharska A, Noczyńska A. [Diabetes type 1 with preserved residual secretion of insulin - case report]. Endokrynologia Pediatryczna. 2014; 13(1, 46): 75-79 (in Polish).

7. Peczyńska J, Peczyńska J, Jamiołkowska M, Polkowska A, Zasim A, Łuczyński W, et al. [Epidemiology of diabetes type 1 in children aged 0-14 in Podlasie Province in years 2005-2012]. Pediatr Endocrinol Diabetes Metab. 2016; 24(1): 14-19 (in Polish). https://doi.org/10.18544/PEDM-22.01.0045

8. Ministerstwo Zdrowia [Internet]. Warszawa: Ministerstwo Zdrowia. [A child with diabetes] [cited 2018 Aug 20]. Available from: http://www.mz.gov.pl/zdrowie-i-profilaktyka/zdrowie-matki-i-dziecka/dziecko-zcukrzyca/ (in Polish).

9. Trojanowska A, Trojanowska P, Brodowicz M, Rzeczycka I. [Preparing children with diabetes to healthy lifestyle]. Endokrynologia Pediatryczna. 2015; 14.2.51: 47-54 (in Polish).

10. Editorial Team. [Patient as the active partner in diabetological care - „patient-centred care” in practice]. Medycyna Metaboliczna. 2017; XXI(1-2): 8-9 (in Polish).

11. Stefanowicz A, Birkholz D, Wójcicka B, Wierzbicka M, Myśliwiec M, Balcerska A. [The role of a nurse in the education of a person suffering from diabetes type 1 and their family]. Probl. Pielęgniarstwa. 2009; 17(4): 346-349 (in Polish).

12. Wójcik M, Pasternak-Pietrzak K, Fros D, Kobyłka A, Krawczyk-Ożóg A, Wołek M, et al. [Physical activity of the children and adolescents with diabetes mellitus type 1]. Endokrynologia Pediatryczna. 2014; 3(48): 35-44 (in Polish).

13. Dąbska 0, Żołnierczyk-Kieliszek D. [The level of knowledge about diabetes: survey based on the group of students from selected universities in Lublin]. Pielęgniarstwo i Zdrowie Publiczne. 2016; 6(4): 285-293 (in Polish). https://doi.org/10.17219/pzp/64036 
14. Janeczek I, Machaj M, Panczyk M, Sienkiewicz Z, Gotlib J. [Assessment of nursing students' knowledge about type 2 diabetes mellitus]. Pielęgniarstwo Polskie. 2017; 2(64): 209-219 (in Polish). https://doi.org/10.20883/pielpol.2017.26

15. Kocka K, Dziedzic U. [Knowledge of secondary school students about type 2 diabetes risk factors]. Medycyna Ogólna i Nauki o Zdrowiu. 2013; 9(3): 255-261 (in Polish).

16. Kłys E, Gerstenkorn A. [Evaluation of nursing female students' knowledge level about diabetes type 2]. Diabetologia Praktyczna. 2005; 6(5): 250-259 (in Polish).

17. Pastwa K. [Assessment of the level of knowledge in patients with diabetes]. Pielęgniarstwo w Opiece Długoterminowej. 2017; 2: 45-55 (in Polish).

18. Olchowska-Kotala A. [Lay knowledge of diabetes - the comparison between family members of diabetic patients and those who had no family experience with diabetes]. Acta Universitatis Lodziensis. Folia psychologiczna. 2016; 12: 47-59 (in Polish).

19. Kołton R. [Teachers are afraid of taking over the care of children with diabetes type 1 . Interview with Monika Zamarlik - President of the National Federation of Diabetic Children and Youth Aid Organisations] [Internet]. Liszki: Medycyna Praktyczna; 2018 [cited 2018 Dec 5]. Available from: www.mp.pl/cukrzyca/ wywiady/179425,nauczyciele-boja-sie-opieki-nad-dziecmi-chorymi-na-cukrzyce-typu-1 (in Polish). 